\title{
Evidences, Methodologies, Analysis, and the Joy of Historical Research: An Interview with Noble David Cook
}

\section{Evidencias, metodologías, análisis y la satisfacción de la investigación histórica: una entrevista a Noble David Cook}

ADRIÁN LERNER PATRÓN

Princeton University

adrianlerner@princeton.edu

\section{ABSTRACT}

Noble David Cook is a leading historian of the demographic and social history of the Andes and the Atlantic World. In this interview, he discusses the origins of his interest in the histories of Peru, the Andes, and the Iberian Atlantic; the methodological approaches that influenced his work; how he sees the evolution, present and future of the fields of demographic history and Colonial Latin America; the role of the archive in his career; his vital and intellectual links with the city of Sevilla; his collaborations with his wife Alexandra Parma Cook; his long history of engagement with Peruvian scholars; and his perspectives on the current COVID-19 crisis.

Keywords: Andean History, Demography, Disease, Archives, Atlantic History

\section{RESUMEN}

Noble David Cook es un destacado historiador de la historia demográfica y social de los Andes y el Atlántico. En esta entrevista, él expone los orígenes de su interés por la historia del Perú, los Andes y el Atlántico ibérico; los enfoques metodológicos que influyeron en su trabajo; cómo ve la evolución, presente y 
futuro de los campos de la historia demográfica y la América Latina Colonial; el papel del archivo en su carrera; sus vinculos vitales e intelectuales con la ciudad de Sevilla; sus colaboraciones con su esposa Alexandra Parma Cook; su larga historia de compromiso con los eruditos peruanos; y sus perspectivas sobre la actual crisis del COVID-19.

Palabras clave: Historia andina, demografía, enfermedades, archivos, historia atlántica

oble David Cook, Emeritus Professor of History at Florida Interna-
tional University and Honorary Professor of the Humanities at the Pontifícia Universidad Católica del Perú (PUCP), is an eminence in the history of the Andes, historical demography, the history of diseases, the early modern era, the Spanish Empire, and the Atlantic world. In a career spanning fifty-five years and counting, Professor Cook has published half a dozen original monographs, several of them in collaboration with his wife, Alexandra Parma Cook. Most of them have been widely reprinted and translated to Spanish. His record also includes more than 60 articles and book chapters, roughly equally distributed between Spanish and English, dozens of book reviews, numerous prestigious grants and awards, and a distinguished track of professional service. The scope of this oeuvre is equally impressive. His research has decisively contributed to the history of the demographic collapse of the native peoples of the Americas, the history of diseases, the social and cultural history of family in the Atlantic world, the ethnohistory and colonial restructuration of the Colca Valley, the history of evangelization and the Franciscan order in the New World, and the history of Sevilla, among other topics.

Throughout, Professor Cook has shown a sustained commitment to a crucial, sometimes neglected aspect of academic life: engagement with the academic communities in the places about which he writes. He has edited and published four collections of sources in Spanish with Peruvian publishers and translated another one into English. More importantly, he has developed strong bonds with local scholars since the beginning of his career, from the early collaboration with the Collaguas ethnohistorical 
research program to his mentorship of young scholars from Peru and other Latin American nations. As part of this sustained engagement with local academic communities, he has been close to Histórica since the journal's establishment in 1977. A founding member of the editorial board, he has also contributed half a dozen original articles to these pages. It is therefore with great pleasure that we welcome back Dr. Noble David Cook to Histórica for this interview.

[A.L] How did you become interested in the colonial history of the Andean region and the Iberian Atlantic?

[N.D.C.] Sometimes people are drawn into another world by a powerful novel, and I must admit that I was compelled some six decades ago when I read Ciro Alegría's El mundo es ancho y ajeno to learn more about the people of the Andes. The works of novelist and ethnologist José María Arguedas, especially Yawar Fiesta, also stimulated my interest in exploring the Andean world and its peoples. I believe it was Aymara specialist William Carter, later Director of the Hispanic Division of the Library of Congress, who was directing a seminar in anthropology at the University of Florida who recommended the two books. I have always been more concerned about knowing more about less well-known subjects than those that are, let us say, thoroughly studied. The Anglo-Atlantic and Mesoamerica were and still are regions that have received close attention of scholars despite the rich cultural heritage of the «others». My aim has been throughout, as much as possible, to use a comparative approach to the broader Atlantic World. Today I would go further and aim for the global world because interconnections existed from the early modern world, or before.

[A.L.] You have described yourself as influenced by the Annales School and the Berkeley School of Historical Demography. Among Latin Americanists, you are perhaps also associated with ethnohistory and microhistory. Could you tell us more about these influences, and in particular about how do you see them interact with each other? 
[N.D.C.] Indeed, I was influenced by the so-called Berkeley School of historical demography, especially Woodrow Borah and Sherbourne F. Cook [no relation] as well as the principal figures of Andean ethnohistory. I read Borah's short monograph on New Spain's Century of Depression in my senior year seminar of the BA. In it Borah linked indigenous depopulation with economic decline and I decided for my MA thesis at the University of Florida to test to see if there was a similar process in Andean America at the same time. During graduate studies I became equally impressed by works of members of the Annales School, especially Fernand Braudel, Pierre Chaunu, Emmanuel Le Roy Ladurie, and Pierre Goubert. The links between historical demography and ethnohistory are intimate in much of my work, after all, they are two elements of social history. Cultural history encompasses all. The Annales School provides a sort of umbrella, covering all the disciplines, old and new. One might think of it as the Russian dolls, one smaller, and so forth. During graduate studies I took courses in anthropology, historical geography, and demography. My doctoral studies were at the University of Texas where I met and studied with Nicolás Sánchez Albornoz who was one of my mentors and a close friend over the decades.

My dissertation was narrowly based on demographic data to determine the size and changes in the Amerindian population of Peru between 1570 to 1620 , a period when evidence was good. I began dissertation research in July of 1967 in the Archivo General de Indias (AGI) in Sevilla, and in the manuscript collections in the Biblioteca Central de la Universidad de Sevilla. I located other important documents in the Archivo Histórico Nacional, the Biblioteca Nacional and Real Academia de la History in Madrid. Before leaving for Peru aboard a ship in late January of 1968, I was fortunate to secure microfilms of several manuscripts. Thanks in part to Pablo Macera of the Universidad Nacional Mayor de San Marcos (UNMSM) I edited two volumes of primary sources for Peru's population that have been widely used. They include the census of the Indians living in the city of Lima in 1614 (1968) and the 1570s central and south Andean tribute assessment conducted by Viceroy Francisco de Toledo (1975). I also edited a facsimile of a population census of 
the inhabitants of the capital city of Lima in 1700 (1985). Let me reiterate, the Annales School allows for the analysis of the "whole» of past societies, and periods, either for the longue durée of a century or many, or the approach of the short «micro" period - a lifetime, an event, that allows for a thorough entrance into the mind, mentalité of individuals of a specific time, place, or event. Social structure, language, religion, environment, demography and so forth are part of the equation, and our book, People of the Volcano: Peruvian Counterpoint in the Colca Valley of Peru is a good example.

[A.L.] Part of your academic production has dealt with the causes, characteristics, and scale of the demographic collapse of the indigenous population of the Americas after the Columbian exchange. How has the knowledge of the field changed in the last couple of decades?

[N.D.C.] Here I will make comment on my current take on the changing historiography over the last half century, so let us start with foundations around 1970 . As you suggest the focus to the mid- $20^{\text {th }}$ century was causes, characteristics and scale, and the arguments between scholars from one extreme to the other. What was needed was a systematic approach to the problem based on more detailed research and new methodologies. Earlier estimates were based on eyewitness reports, ranging from captains and soldiers to clergy and settlers. The numbers were wide ranging, from hundreds of thousands to multiple millions. The arguments about causes, whether they were deaths from disease or mass murder, with every possibility in between, the positions taken were largely based on ideology rather than systematic, meticulous data collection and scientific analysis. By mid-century the New Social Sciences were reaching maturity -anthropology, archaeology, demography, economic history and so forth. Increasingly interdisciplinary cooperation led to new methodologies, ethnohistory, historical demography, with new technology contributing to revisionism. Take for example historical demography or economic history that are heavily data driven. The computer permits rapid analysis of millions of numbers associated with numerous factors. In terms of archaeology the advances in recent decades are incredible. My comments 
three decades ago on the slowness of the field are no longer true, for in many respects they are advancing more rapidly than others, thanks to technology - satellite reconnaissance, infrared photography, DNA analysis, and others too numerous to mention here. The checks for investigation relate to rising populations pressing archaeological sites, political instability, and resistance to disturb sacred places.

[A.L.] According to your estimates, the indigenous population of the Andean region was likely decimated in the century and a half that followed the European invasion. What are the effects of a catastrophe of such magnitude? What are the implications of the demographic collapse to understand the history of the native peoples?

[N.D.C.] Indeed, there was a sharp drop in the indigenous population in the Andean region and in general throughout the Americas in the first 150 years, and terms such as decimation, catastrophe, collapse are useful, but not holocaust as some have labeled it. The effects, or consequences of this rapid drop are significant, but do not necessarily change all. There are regional, even local variations in mortality in the Andean area, and human and environmental variations are important for the impact of an epidemic. Population densities and migratory patterns are closely related to the spread and mortality of disease, and here there are sharp variations. There can be total loss of population on a small island, or a narrow valley, or a small settlement in Amazonia, but other places, even nearby, can be spared. Nutrition is also a key in protection of health. The reality is that in many places, despite disease, overwork and malnutrition, those who died were replaced soon by new generations. Review of death, marriage and birth records point to rapid replacement, even in the early period. As one examines the Andean highlands, native depopulation stabilizes relatively early despite the encomienda and mita (labor drafts). Certain diseases that were most dangerous in tropical or temperate climates were less of a problem above 3,250 m. elevation. In spite of the chaos and destruction caused by Old World peoples on the New, the original Americans persisted, and by the mid-twentieth century the population of some groups was as large as it was in the early 16th century. Now it 
is much, much larger and in many groups the languages, a foundation of culture, and foods and religious beliefs have persisted. Debates over the causes, size of the original population, the magnitude of the loss in decades following contact, and the causes for the deaths continue.

[A.L.] Do you think historians of culture, politics, economics, and other fields of Latin American history have done enough to integrate the importance of this process to their own research?

[N.D.C.] I expected greater interdisciplinary cooperation decades ago, but progress is still less today than I hoped for. There seems to be an inertia to maintain the disciplines apart, and the area studies programs and associations that did foster interdisciplinary collaboration now seem to be under pressure that is ill advised. Universities are currently under intense pressure to adopt business managerial models for so called efficiency and cost savings. Such efforts are unfortunately emaciating academia and leaving students with a truncated education.

[A.L.] Some of your publications are co-authored with your wife, Alexandra Parma Cook. How has this process of collaboration worked?

[N.D.C.] This is a great question, one that we have had many conversations about. I suspect, no proof, that few couples attempt it, and fewer survive. For us, working together is a pleasure, a joy, at all stages but especially during the period of original research. Alexandra (Sasha) and I enter a project with an open mind, knowing that we are aiming to write about, but aware that we will follow the crumbs of evidence wherever they lead, and if there is a dead end, we are ready to shift directions. A good example, keeping in mind your question of the impact of the Annals School in our work, is a recent book on Spanish history, The Plague Files: Crisis Management in Sixteenth Century Seville (2009). The book is a microhistory, and the personal testimony of the people who were involved, from the words of ill workers to barber surgeons and trained physicians, the governor and city officials, and merchants and ship owners who were fighting quarantine. From the late 1980s we stayed in the barrio of Triana of Seville while conducting archival research. 
We became increasingly interested in the early modern period history of Triana and its relation to the Americas. We were consulting various archives including the AGI, the parish archive of the church of Santa Ana, notarial records and the municipal archive where we discovered a manuscript «libro de la peste» that included details on the handling of an epidemic series that hit Andalucía in the early 1580s. Our interest quickly shifted as we started digging deeper into the documents and trying to bring to life the impact of not one crisis, but several, that were hitting the area. We wanted to recreate as best as possible the role of the governor and city officials confronting epidemics, a war with Portugal, stationing of foreign troops, crop failure and starvation, bankruptcy, and a Morisco rebellion, all during the short administration of Don Fernando de Torres y Portugal, the Conde del Villar, who was subsequently, as you know, the Viceroy of Peru. We discussed our new findings during our mid-morning escapes for a cafecito and tostada, as we rested our eyes, and during evening tapeos. What could be more enjoyable teamwork than this?

[A.L.] Your monographs reveal a particularly strong engagement with archival material, from the richness of the extraordinary case in Good Faith and Truthful Ignorance, to the meticulous combination of historical sources with epidemiological models in Demographic Collapse. Could you tell us more about your relationship with the archive?

[N.D.C.] Indeed, our book on the encomendero of Yanque Collaguas in the Colca Valley required mining diverse materials in numerous archives to reconstruct the lives of Francisco Noguerol de Ulloa and his two wives, as we detail in the book. We began the serious research in the AGI in 1984 as we probed the hefty legajos with the court cases directed against him, as well as all the other letters and reports in other sections of the archive. Having dealt with his career in South America, we needed to complete the story and what happened regarding the legal action taken by his first wife, and that took us to the city of Medina del Campo were he and the widow he married while in Peru settled. We worked in the municipal archive in Medina in evenings (temporarily 
housed in the Biblioteca Municipal) and in the mornings we commuted to Valladolid to work in the notarial records housed there. It was there that we were able to bring this amazing saga to its conclusion. Here is a narrative that tells much of the concept of honor, the nature of marriage and family, role of women, acquisition of wealth, and the Spanish legal and administrative systems.

The Plague Files is another example of our dedication to the raw documents we use to reconstruct as accurately as possible human existence. Past «reality» is not in the minds of philosophers of history pontificating in an ivory tower. To dig out the reality one needs to be where the sources are, in the dust and disintegrating texts in the archive. The nature of the source can be the written, or a myriad of other archival repositories film, music, audio, fashion, etc. We have at times refused to read the work of other historians on a topic, place and time we are researching in order to avoid contamination, or better, influences of other historians. We engage with other historians as we are nearing the end of our trajectory and presentation of the results. In the final stages we can and do elaborate on the similarities and differences in our conclusions. I do not necessarily recommend this technique for graduate students or young faculty, because of the pressure of time to complete the dissertation, or first book for tenure or promotion.

[A.L.] How do you see the present and future of the field of Colonial Latin American history? Is it in a healthy state, both in terms of its intellectual evolution and of its institutional and professional development? What are some of the most exciting developments and most difficult challenges in these two realms?

[N.D.C.] I believe there will always be a place for Colonial Latin American History, after all, it is foundational for the understanding of what follows. The culture, broadly defined, is based on the nature and mix of Old World and New World cultures, and it varies in theme and focus and continues to unfold as the generations sweep by. There are and will be arguments about the chronology and the nature and timing of a Middle Period and the contemporary. Many of the major journals 
of Latin American history have reduced sharply the number of articles published on the colonial period, but the Colonial Latin American Review retains its focus, as does the Colonial division of the Latin American Studies Association and there is also a colonial section in the Conference of Latin American History. The colonial period coverage is still significantly present in Peruvian and Mexican journals. There is a significant number of new young and dynamic colonial period scholars who are using modern communications to organize conferences centering on underexplored themes that are of critical societal interest. Edited books centering on conferences, e-books and e-journals are increasing, and quickly bringing the results to the academic audience.

[A.L.] What would you say to young historians beginning a career in the field?

[N.D.C.] Over a five decade plus career I have witnessed several collapses in the professional job market. I began teaching in 1969; by 1972 there were virtually no open positions available for the next five years. We are currently facing a crisis that may be one of the worst. These in the past have been cyclical, lasting a half decade or so, and many excellent PhDs gave up the profession, but most found a satisfying career because history provides the skills required for many fields. By the way, many historians and other academics are retiring early because of the current COVID-19 pandemic. Another positive possibility - the current global political upheaval in democracies is partly the consequence of a poorly educated public, and a knowledge of history and civic responsibility is key to re-establish social order and justice. There is a critical need for more classes in history, not fewer!

[A.L.] Some of your current work focuses on Sevilla. Can you tell us more about what at took you to focus on the city?

[N.D.C.] My first experience with Sevilla began in the summer of 1967 when I arrived to begin dissertation research. It was in the time of Franco's dictatorship and economic hardship and one felt a leaden depression daily in one fashion or another. Research was centered in the 
AGI, in the original building with neither air conditioning in the summer nor heating in the winter, and the staff was small. By January of 1968 when I set forth from the docks in Barcelona destined for the port of Callao. I knew Sevilla, Andalucía plus Castilla would never be out of my mind. My next return was brief for research in summer of 1970 to refresh after my first hectic year, four or five courses per semester, at the University of Bridgeport, Connecticut. It would be several years before I returned to Spain. My wife and I were in Peru in 1977, thanks to the Wenner-Gren Foundation, conducting six weeks of research in the parish archive of Yanque in the Colca Valley, and the equivalent time in the Biblioteca Nacional and the Archivo General de la Nación in Lima. By then we had ample material to return to Spain to continue research on the ethnohistory of the Colca Valley. We went to Spain in the summer of 1982, which was Sasha's first trip to Spain. She fell in love with the country and culture. Our base was Madrid, and our research was Monday to Friday, with weekends devoted to intense regional tourism. In quick succession I returned to Peru, thanks to Franklin Pease and the Fulbright Commission to teach at the PUCP during much of 1984, and then continue research in Spain with support of the Comité Conjunto Hispano-Norteamericano para la Cooperación Cultural y Educativa from January to August 1985. When we reached Sevilla and settled in Triana, it instantly became our second home. Triana is a village within a city, where everything necessary is within a ten-minute walk. Furthermore, it is within walking distance to the AGI and other archives. We returned to Sevilla in subsequent years to continue research on the Colca Valley and one of the doctrineros there, Luis Gerónimo de Oré, a Franciscan friar from Huamanga who ended his career in Chile, as bishop of Concepción. At the same time, we conducted research in the Archivo Parroquial de Santa Ana de Triana with José Hernández Palomo of the Escuela de Estudios Hispanoamericanos and his wife Mari Luz Peña, which resulted in a joint publication of an article on «Epidemias en Triana (Sevilla, 1660-1865)». Sasha and I became interested in the history of Triana, shrouded in myths of sailors and gypsies, and we knew that in order to get a better understanding of the barrio and its inhabitants we 
needed to tackle the notarial records. From our first visit to the notarial archive in Sevilla we have been diligently collecting information to write a detailed socio-economic history of the district of Triana and its relation to the Americas in the period 1570-1620. We have already published short articles, Sasha centering on women and I on manufacturing.

[A.L.] Throughout the years, you have established important links with Latin American scholars and institutions, not the least in Peru. What have been some of these experiences, and how have they influenced your career?

[N.D.C.] There are three or four different types of experiences students, other researchers in the field, fellow academics, and critical enablers. I believe that the teacher is also a learner, or should be, so I begin with a sample from my 1974 and 1984 seminars at the PUCP - Guillermo (Willy) Cock and Efraín Trelles, members in the initial Colca Valley reconnaissance team who published their work in Collaguas $I$ (1977), edited by Franklin Pease. Willy has continued to be a major figure in the field of archaeology and Efraín wrote one of the best microhistories on the encomendero Lucas Martínez Vegaso before continuing as a journalist. Sanmarquino Francisco (Paco) Quiroz Chueca went on to CUNY for the Ph.D. and has published five books and numerous articles on economic and social history broadly defined. He is presently the vice dean of the Social Sciences Faculty at the UNMSM. Thanks to my affiliation with the PUCP I have helped bring several students to Florida International University (FIU) in Miami to work toward the doctorate - Miguel Costa Vigo, Renzo Honores, Sandro Patrucco, and Judith Mansilla. I collaborated with Miguel, a close friend, in teaching, guest lecturing and in research. I was dissertation director for both Miguel and Renzo, and books based on their dissertation results should be published. Sandro has produced several works. Judith is now a permanent lecturer at FIU and her first book is being published here.

My closest ties and most extensive collaboration with academic colleagues were with Franklin Pease. That relationship includes our families, extends back for decades and continues to this day with Franklin's widow Mariana 
and their children. Franklin's enthusiastic acceptance of the New Social Sciences, and in particular his interaction with anthropologists John Murra, María Rostworowski, and Tom Zuidema, the impact of the suicide of José María Arguedas in 1969, and our extended conversations about the relation of historical demography and the impact of ethnohistory, including myth-history and of course Andean religiosity were insightful and were one element that led to our collaboration, and reciprocity, whether I was based in Connecticut or in Florida. In addition to our joint work on the initial Colca Valley project, Franklin established in 1977 the journal Histórica to publish the best of historical scholarship by national and international specialists, including the New Social History. It has been very successful, and following Franklin's untimely death, the quality has been maintained thanks to the dedication of its initial and current editors, José de la Puente Brunke and Pedro Guibovich Pérez. Franklin also founded the early platform of the Programa de Estudios Andinos at the PUCP. The Program has received international recognition and continues under the able direction of Marco Curatola. I have benefited from working and interacting with the members of the PUCP and developed many friendships. These relationships are enormously gratifying, as I tell academics and students elsewhere. Sasha and I have met many of the "younger" scholars in Seville, including Margarita Suárez, and kept up our friendship over the years. Unfortunately, we would quickly run out of space if I listed all my Peruvian colleagues and friends, not just at the PUCP but other institutions around the country.

It was Miguel Maticorena who I met at the AGI in 1967, who led to my relationship with Franklin Pease. He not only gave me suggestions on where I might find population data, he also wrote letters to Peru informing several people of my coming trip to Peru — Franklin Pease and Pablo Macera among others. Some of Macera's students were conducting research in the AGN then in the Palacio de la Justicia, and a meeting was set up, followed by an invitation to join in his frequent tertulias in his home near the Stadium. He was for various reasons interested in my research on Andean population and change, especially the microfilms, 
and he suggested I edit and publish the Padrón de los indios de Lima en 1613 (1968) which I did in his Seminario de Historia Rural Andina by the UNMSM. His student Mauro Escobar Gamboa prepared the transcription. After several delays because of political and economic issues, the UNMSM published my edited Tasa de la visita general de Francisco de Toledo (1975). Over the years I maintained a good relationship with Macera, though there was less frequent interaction and I found his students, many who later taught at the UNMSM or at provincial universities, to be doing excellent research and publications, including Manuel Burga and Lorenzo Huertas, and many others, including Victor Peralta and Paco Quiroz.

[A.L.] As a specialist in the history of epidemics in the Americas, how have you experienced the ongoing COVID-19 pandemic? What can we learn from those past experiences?

[N.D.C.] As measles and smallpox, two of the most mortal Old-World diseases introduced into the Americas, COVID-19 is primarily passed by aerosols rather than by a vector. The time from infection to symptoms is rapid and one can be contagious for several days. Since the current world population is «virgin soil» for the Corona virus and the disease can damage major organs, depending on numerous factors, the virus will be with us until there is a vaccine or the virus mutates into a form that is less mortal for homo sapiens. Currently quarantine is the only way to contain it, use of masks, social distancing and washing helps check the spread of the disease. By the sixteenth century it was clear that the best way to survive a deadly epidemic was to establish an effective quarantine. Some might attempt to «flee, flee fast and flee far", potentially spreading the disease. Our book on managing a series of epidemics, bubonic plague, influenza and typhus, in Sevilla in the early 1580s provides a guideline that could be useful even today for the early stages of a new and deadly pandemic. The governor of Seville and its district, the Conde de Villar, along with city officials, set up a medical board, and officials working together enforced strict quarantine, similar to what the Chinese did this year! The Conde's next assignment was as Viceroy of Peru, during 
the time of the epidemic of smallpox, measles, typhus, influenza sweeping through the Andes with the greatest impact on the indigenous peoples. Although he attempted similar procedures to check the disease spread in the Lima district, he was unsuccessful. What have we learned? If some nations today chose herd immunity rather than what Seville's city officials were doing in the sixteenth century to stop the spread, it seems clear some have not learned anything. Nevertheless, most countries do rely on scientific knowledge and vaccination will soon be available, which was not the case in premodern societies.

Fecha de recepción: 11/XI/2020

Fecha de aceptación: 22/XII/2020 